\title{
HOST ATTRACTANTS FOR THE BANANA STEM BORER, Odoiporus longicollis (COLEOPTERA: CURCULIONIDAE): IDENTIFICATION, ELECTROPHYSIOLOGICAL ACTIVITY AND BEHAVIOURAL BIOASSAY
}

\author{
NEELAKANTHI E. GUNAWARDENA* and SAMADARA DISSANAYAKE \\ Department of Chemistry, University of Kelaniya, Kelaniya
}

(Received: 07 October 1999 ; accepted: 26 March 2001)

\begin{abstract}
Steam volatiles of tieshly cut hanana stem were analyzed by combined gas chromatography- electroantennographic detection (GC-EAD) and combined gas chromatography-mass spectrometry (GC-MS) to identify n-hexanol, n-hexanal, $n$-pentanol and cis-3-hexenol as host attractants for the banana stem borer; Odoiporus longicolli, is. Identities of the above compounds were confirmed by comparative studies with authentics. Female weevils responded slightly more (EAG 1.41 0.01) than male weevils (EAG 1.04 \pm 0.03 ) to the steam distillate. Synthetic equivalents of the above attractants were subjected to EAG assay and n-hexanol elicited the highest EAG response $(0.39 \pm 0.02 \mathrm{mV})$ in the antenna of this weevil. The other synthetic attractants, n-hexanal, n-pentanol and cis-3-hexenol elicited EAG responses in the following order; $0.15 \mathrm{mV}, 0.10 \mathrm{mV}, 0.09 \mathrm{mV}$. A mixture of the above synthetic attractants (SAM) also elicited a poor EAG response $(0.2 \mathrm{mV})$ in O.longicollis. In tield experiments n-hexanol singly or in combination with the aggregation pheromone of $O$. longicollis failed to attract any weevils into traps. The synthetic attractant mixture (SAM) also was not field attractive while its combination with the aggregation pheromone of $O$. longicollis was attractive with a maximum. mean catch of $0.66 \pm 0.21$ weevils / trap/week. Under the same conditions, howevej; the pest's known attractant system, the aggregation pheromone + hanana stem tissue baited trap, had a maximum mean catch of $29.16 \pm 7.02$ weevils/ trap/week.
\end{abstract}

Key words: Banana stem borex, n-hexanal, n-hexanol, cis-3-hexenol, host attractants, Ocloiporus longicollis and n-pentanol.

\section{INTRODUCTION}

Banana (Family: Musaceae) is one of the most important fruits in the South East Asian region. A large number of banana clones used over the world derive originally from two wild species, Musa acuminata and Musa balbisiana. ${ }^{1}$ At present, Sri Lanka has 29 clones of banana of which many are indigenous to the country. The country has a favourable climate for banana and a total of about 45,000 hectares of banana has been recorded for the year $1995 .^{2}$

Banana cultivators in the region are troubled by two weevils, the banana stem borer, Odoiporus longicollis ${ }^{3}$ and the rhizome borer, Cosmopolite sordidus. ${ }^{3,4}$ Female $O$. longicollis lay eggs in the stem (pseudo stem) and bunch stalks of the banana tree. The larvae tunnel through the stem tissue, making it weak and liable to get blown down.

${ }^{*}$ Conresponding author 
This pest is controlled by chemicals such as DDT, BHC, aldrin and dieldrin used as the soil treatments with repeats every 6-12 months. In some areas the base of the banana stem is painted upto about $50 \mathrm{~cm}$ with tar or mud slurries containing insecticides to prevent attack by $O$. longicollis. ${ }^{5} \mathrm{~A}$ liberal spraying of insecticides in the insect's hiding sites has been found to be an efficient method to control this pest.. In some areas of Sri Lanka, mass trapping of this pest using split banana pseudostem is being practiced. The only biological control method reported for banana weevils is the use of predators and parasites.

Studies on attractants for banana pests have been limited mainly to aggregation pheromones. Beauhaire et.al.identified the aggregation pheromone of $C$. sordidus in 1995 as a terpenoid ketal. ${ }^{4}$ This was shown to be field active only in the presence of host tissue. We earlier reported the identification of male aggregation pheromone of O.longicollis as 2-methyl 4-heptanol." "9 This pheromone was also found to be field active only in combination with banana stem tissue. ${ }^{11}$ The present paper reports the identification of several host attractants from banana stem tissue. Attempts have been also made to use synthetic equivalents of the identified attractants as field baits. In this study we have used a banana cultivar widely grown in Sri Lanka (Seeni Kesel) a triploid (ABB) whose volatiles were highly attractive to the above pest.

\section{METHODS AND MATERIALS}

Insects. Adult $O$. longicollis were collected from rotten banana plants in the District of Gampaha, Sri Lanka. They were separated by sex, kept at a temperature of $25 \pm 2{ }^{\circ} \mathrm{C}$ and $\mathrm{Rh}$ of $80 \pm 4 \%$ and fed with banana stem tissue.

Steam Distillation: Fresh banana stem cut into small pieces $(1 \mathrm{Kg})$ was steam distilled for $4 \mathrm{~h}$ in an all glass apparatus. The distillate $(110 \mathrm{ml})$ was saturated with $\mathrm{NaCl}$ and subsequently extracted with diethyl ether $(30 \mathrm{ml} \times 3)$. The ether phase was dried over anhydrous magnesium sulfate and concentrated down to $2 \mathrm{ml}$. This solution was kept at $4{ }^{\prime \prime} \mathrm{C}$ to be used later in bioassay and analytical studies. Using the above procedure, steam distillates of four varieties of banana, all triploids viz Seeni Kesel (ABB), Ambul Kesel (AAB), Anamalu (AAA) and Kolikuttu (AAB) were prepared for a bioactivity comparison.

Behavioural Bioassay: The attractant properties of banana varieties were compared by a behavioural bioassay using a Y-shaped glass olfactometer. ${ }^{10}$ The olfactometer was covered with black paper in order to facilitate free movement of weevils inside the tube. Appropriate doses of steam distillates were absorbed into filter paper strips and solvent was allowed to evaporate. This was next inserted in to one arm (e.g. A) of the olfactometer. Blanks were prepared from filter paper strips containing similar amounts of diethyl ether and inserted into the other arm (e.g. B) and this sequence was interchanged in subsequent replicates. Weevils, starved $3 \mathrm{~h}$ before 
the bioassay, were released into the third arm of the olfactometer gradually. Weevils that did not move into the baited arm within 3 min were considered non-responders. Each test substance was assayed using 6 batches of weevils each consisting of 5 males and 5 females.

Analysis of volatiles: Steam volatiles were analyzed on a Hewlett Packard 5890 series II chromatograph equipped with fused silica capillary columns $(30 \mathrm{~m} \mathrm{x}$ $0.25 \mathrm{~mm}$-ID $0.25 \mu \mathrm{m}$ film thickness, J \& W Scientific California) coated with DB 5 stationary phase, a flame ionization detector (FID). Helium was the carrier gas at a flow rate of $1 \mathrm{ml} / \mathrm{min}$ and nitrogen at $30 \mathrm{ml} / \mathrm{min}$, the make up gas with a temperature program: $40^{\circ} \mathrm{C}\left(5 \mathrm{~min}\right.$ ) from $40-170^{\circ} \mathrm{C}$ (rate $5^{\circ} \mathrm{C} / \mathrm{min}$ ), from $170^{\circ} \mathrm{C}$ to $250^{\circ} \mathrm{C}$ (rate $20^{\circ} \mathrm{C} / \mathrm{min}$ ) and finally at $250^{\circ} \mathrm{C}$ for $10 \mathrm{~min}$.

Gas chromatography-mass spectrometric (GC-MS) analyses were performed with a Hewlett Packard 5890 Series II gas chromatograph, fitted to a HP 5870 Series mass spectrometer with electron impact (EI) mode at $70 \mathrm{eV}$. GC column parameters were similar to those described previously, however, with the following temperature program; $40^{\circ} \mathrm{C}(5 \mathrm{~min})$, from $40-170^{\circ} \mathrm{C}$ (rate $5^{\circ} \mathrm{C} / \mathrm{min}$ ), from $170-250^{\circ} \mathrm{C}\left(\right.$ rate $20^{\circ} \mathrm{C} / \mathrm{min}$ ) and at $250{ }^{\circ} \mathrm{C}$ for $10 \mathrm{~min}$.

Electroantennography: Electroantennograms (EAG) ${ }^{11}$ were recorded from isolated antennae of male or female $O$. longicollis using glass capillary electrodes filled with saline solution and connected to gold wire. The reference electrode was inserted into the base of the antenna and the recording electrode into the antennal cone. The electrical signal was fed into an amplifier and displayed on a computer screen (Gateway 2000).

EAGs were recorded for different doses of banana stem-steam distillate, individual synthetic attractants (n-hexanol, n-hexanal, n-pentanol, cis-3-hexenol) and a synthetic attractant mixture consisting of $n$-hexanol, $n$-hexanal, $n$-pentanal and cis-3-hexenol, made by mixing $0.36,0.24,0.16 \mathrm{~g}$ and $0.21 \mathrm{~g}$ respectively. These compounds in the above proportions were found to occur in the banana steam volatiles. For the above experiment both male and female weevils were used. Each sample was tested on six antennae (male and female). An external source of $1 \mathrm{mV}$ was used to calibrate the EAG response. As correction for antennal fatigue, the response to reference substance $(100 \mu$ l of steam distilled extract of banana) was measured between test samples. Each dose was delivered onto a filter paper: strip (3 X $30 \mathrm{~mm}$ ) placed inside a glass Pasteur pipette $(0.5 \mathrm{~mm}$ ID X $100 \mathrm{~mm})$.

To record the dose response curves of male and female $O$. longicollis, eight doses $(1,5,10,50,100,200,300,500 \mu l)$ of the banana steam distillate were tested. Each dose was delivered as $100 \mu \mathrm{l}$ aliquots in order to maintain a constant volume in samples. Thus doses having less than $100 \mu$ were diluted whilst those which had a volume more than that were concentrated until the sample size reached $100 \mu$. 
Coupled gas chromatography-electroantennographic detection: GC-EAD was performed with the same GC described earlier but with a splitter fitted into the column. Effluents were split between FID and antenna in the ratio 20: 80 respectively. A make up gas of nitrogen $(30 \mathrm{ml} / \mathrm{min})$ was added to the splitting device to accelerate the exit of GC effluent towards the antenna. The effluents from chromatograph were driven through a heated transfer line $\left(200^{\circ} \mathrm{C}\right)$ in order to prevent any condensation. The EAG and FID signals were synchronized using a GC-EAD response of $R$. ferrugineus antenna to its aggregation pheromone.

Field assay: Following the method described previously, ${ }^{12}$ field experiments were conducted in banana plantations in Kadawata in the District of Gampaha from May-July 1997. White plastic buckets (capacity 5L, diameter $21 \mathrm{~cm}$, height $17 \mathrm{~cm}$ ) filled with soapy water $(1.5 \mathrm{~L}$ ) were used as traps. Bucket traps were attached at 3-4 feet height to strong wooden poles (posted near the banana plant) in randomized blocks with traps at $20 \mathrm{~m}$ intervals and blocks $1 \mathrm{~km}$ apart. Six candidate baits and two controls (see later) with 6 replicates each were tested. Attractants filled into glass capillaries (20mg in each) were suspended inside the bucket just above the water level. Rate of evaporation of attractants from similar capillaries was determined to be $400 \mu \mathrm{g} /$ day. One end of the capillaries was opened at the site, prior to the start of the experiment. Test baits used in traps were, $n$-hexanol, the synthetic attractant mixture (SAM) and SAM in combination with the synthetic aggregation pheromone, 2-methyl-4-heptanol' (1:1, w/w). In preparing the above combinations, attractants were not mixed into one capillary but were kept in different capillaries. As the two controls, a blank (a trap with no attractants) and a known attractant system" were used. The latter consisted of the aggregation pheromone + small pieces of fresh banana stem tissue $(800 \mathrm{~g})$ placed inside the bucket (in water). Trap catches were counted weekly for 6 weeks.

\section{RESULTS}

\section{Bioactivity of steam distillates}

EAG activity: EAG response profiles of both female and male $O$. longicollis to the steam distillate were similar, female responses being slightly higher than those of the male. The highest EAG responses were observed in male and female antennae at EAGs of $1.04 \pm 0.03$ and $1.41 \pm 0.01 \mathrm{mV}$ respectively at a dose of $100 \mu \mathrm{l}$ (Figure 1 ).

\section{Behavioural assay of the host volatiles of banana varieties}

Volatiles of Seeni Kesel elicited the highest activity by attracting a mean number of 7 weevils out of 10 into the baited arm. This, however, was not significantly different from the mean numbers of weevils attracted by Anamalu and Kolikuttu. The weakest attractant was the volatiles of Ambul Kesel which had a mean of 3.66 weevils in the baited arm (Figure 2). Bioassay using seven doses of the Seeni Kesel steam distillate showed a maximum at $10 \mu$ l (Figure 3 ). 


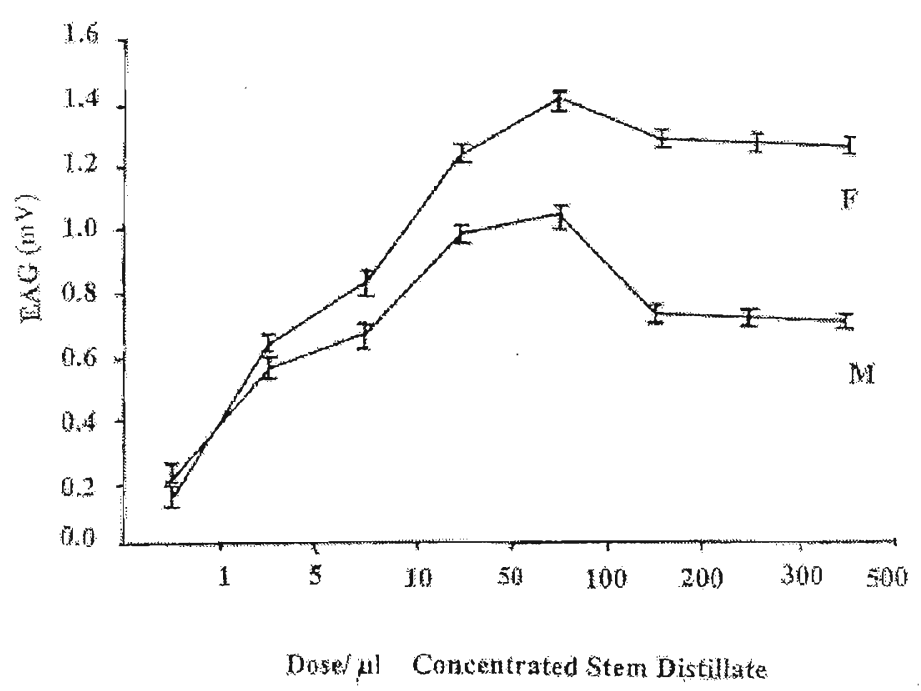

Figure 1: EAG responses of male and female $O$. longicollis to banana stem-distillate. Doses were made from the concentrated steam-distillate.

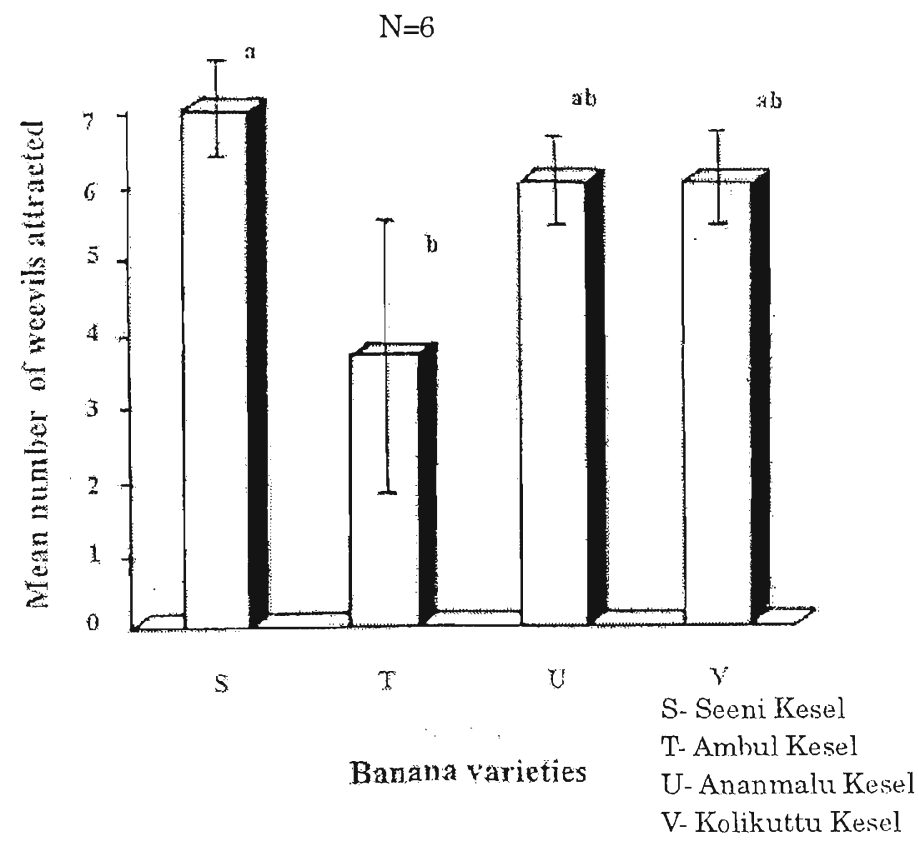

Figure 2: Behavioural response of $O$. longicollis to banana steamdistillates. Bars topped by the same letter are not significantly different, one way ANOVA \& Scheffer's test $P>0.05$. 10 $\mu$ l of each concentrated banana steam distillate was used as bait. 


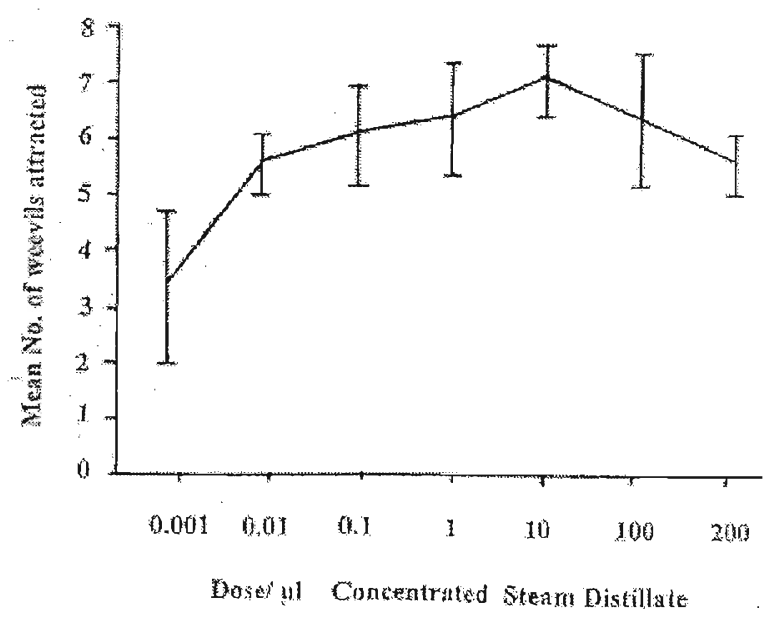

Figure 3: Behavioural responses of O. longicollis to different doses of Seeni Kesel steam-distillate

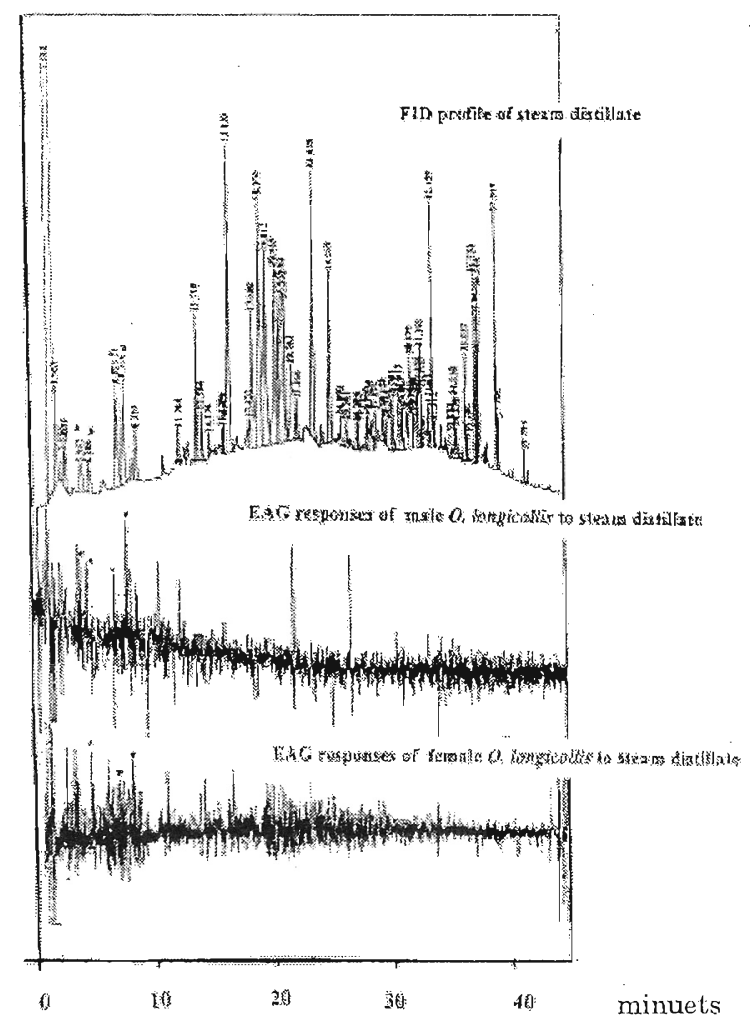

Figure 4: FID and EAG responses of $O$. longicollis to banana steam distillate. 
GC-EAG analysis: GC-EAG recordings from both male and females (six repeats each) showed four EAG responses at 4.27, 5.06, 7.50 and $8.11 \mathrm{~min}$. (Figure 4)

\section{Table 1: GC retention times ${ }^{*}$ of attractant compounds in the banana stem steam distillate and the corresponding standards}

\begin{tabular}{lcc}
\hline \multirow{2}{*}{ Peak } & \multicolumn{2}{c}{ GC retention Times/min. } \\
\cline { 2 - 3 } & Standard Compound & Observed \\
\hline A & 4.19 & 4.27 \\
B & 4.97 & 5.06 \\
C & 7.55 & 7.50 \\
D & 7.92 & 8.11 \\
\hline
\end{tabular}

\footnotetext{
'Gas chromatographic (GC) analyses were perfirmed on a Hewlett Packard 5890) series II cbromatograph. equipped with fused silica capillary columns $(30 \mathrm{~m} \times 0.25 \mathrm{~mm}-\mathrm{ID} 0.25 \mu \mathrm{m}$ tilm thickness, $J$ \& $W$ Scientific California) coated with DB 5 stationary phase, a flame iunization detector (FID). Helium was the carrier gas at a flow rate of $1 \mathrm{ml} / \mathrm{min}$ and nitrogen at $30 \mathrm{ml} / \mathrm{min}$, the make up gas with a temperature program: 40 " $\mathrm{C}(5 \mathrm{~min} \text { ) from } 41)^{\prime \prime} \mathrm{C}-1700^{\circ} \mathrm{C}$ (rate $5{ }^{\circ} \mathrm{C} / \mathrm{min}$ ), from $170{ }^{\circ} \mathrm{C}$, to $250{ }^{\prime \prime} \mathrm{C}$ (rate $20{ }^{\prime \prime} \mathrm{C} / \mathrm{min}$ ) and finally at $250{ }^{\prime \prime} \mathrm{C}$ fir. $10 \mathrm{~min}$.
}

Table 2: Mean trap catch" per trap $( \pm S D, N=6)$ per week

\begin{tabular}{lcccccc}
\hline Week & Hexanol & $\begin{array}{c}\text { Synthetic } \\
\text { Chemical } \\
\text { Mixture } \\
(\text { SAM })\end{array}$ & $\begin{array}{c}\text { Aggregation } \\
\text { Pheromone } \\
+ \\
\text { Hexanol }\end{array}$ & $\begin{array}{c}\text { Aggregation } \\
\text { Pheromone } \\
+ \\
\text { SAM }^{+}\end{array}$ & $\begin{array}{c}\text { Aggregation } \\
\text { Pheromone } \\
+\end{array}$ & $\begin{array}{c}\text { No } \\
\text { bait } \\
\text { host tissue }\end{array}$ \\
\hline 1 & 0.0 & 0.0 & 0.0 & $0.66( \pm 0.21)$ & $0.33( \pm 0.47)$ & 0.0 \\
2 & 0.0 & 0.0 & 0.0 & $0.16( \pm 0.02)$ & $29.16( \pm 7.02)$ & 0.0 \\
3 & 0.0 & 0.0 & 0.0 & $0.00-$ & $20.00( \pm 3.56)$ & 0.0 \\
4 & 0.0 & 0.0 & 0.0 & $0.00-$ & $12.00( \pm 4.12)$ & 0.0 \\
5 & 0.0 & 0.0 & 0.0 & $0.50( \pm 0.30)$ & $6.30( \pm 3.14)$ & 0.0 \\
6 & 0.0 & 0.0 & 0.0 & $0.16( \pm 0.05)$ & $1.66( \pm 1.25)$ & 0.0 \\
\hline
\end{tabular}

"The overall mean catch (over $6 \mathrm{~s}$ weeks) of weevils/ trap for aggregation pheromone+SAM and the control attractant ( $0.25 \pm \mathrm{SD} 0.24$ and $11.58 \mathrm{SD} \pm 10.27$ respectively) were significantly different $(\mathrm{P}<0.05$, one way ANOVA \& Scheffer's test). Both male and females were caught at a ratio of 43:57.

"a mixture of n-hexanol, n-hexanal, n-pentanol and cis-3-hexanol in a proportion similar to that of the banana steam -distillate. 
GC-MS analysis: A comparative study of the mass spectra of the GC peaks A,B,C,D and those of the respective standard compounds identified them as pentanol, hexanal, cis-3-hexenol, and hexanol respectively. Subsequently GC retention times of the above peaks were compared with those of the standards (Table 1).

Comparative EAG assay of synthetic host attractants (individual), a mixture (SAM) and the steam distillate (natural host): The highest EAG response $(0.62 \pm 0.07 \mathrm{mV}$ ) was elicited by weevils to the banana steam volatiles and this was significantly different ( $p<0.05$, ANOVA \& Scheffers test) to all other test samples. Of the synthetic host compounds, the highest mean EAG was elicited by hexanol $(0.39 \pm 0.02 \mathrm{mV})$, the lowest by cis-3-hexenol (Figure 5)

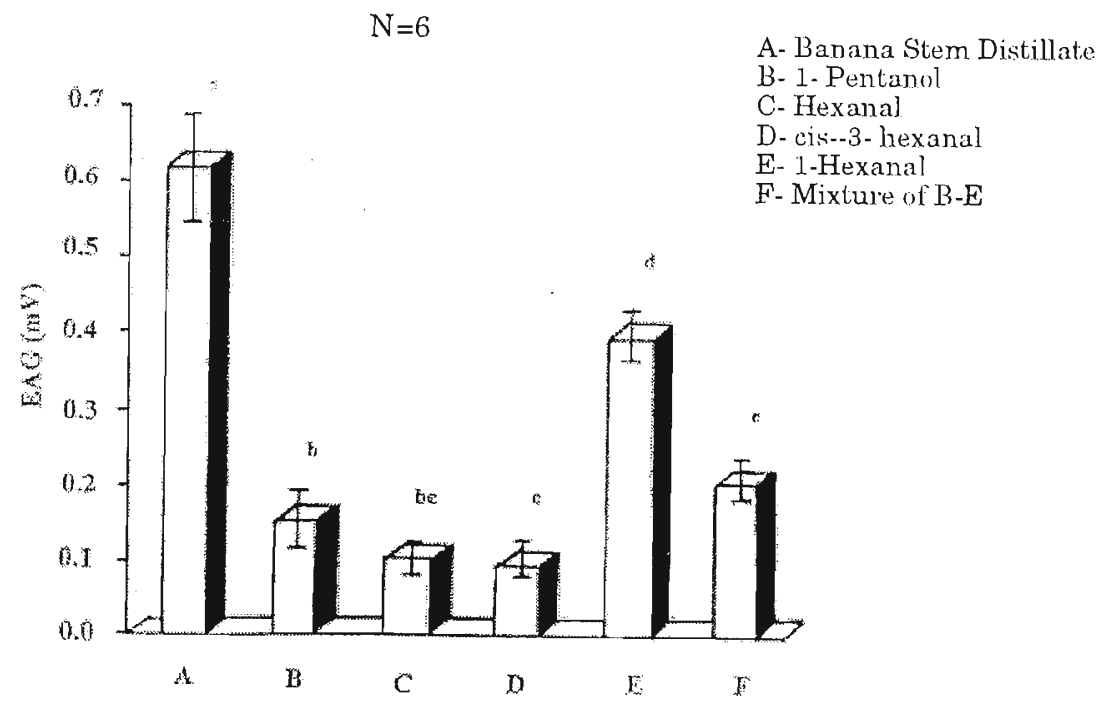

TEST SAMPLES

Figure 5: EAG responses of $O$. longicollis to synthetic host attractants (individual and a mixture of attractants) Bars topped by the same letters are not significantly different, one way ANOVA \& Scheffer's test P>0.05. Doses were taken from $1 \mathrm{mg} / \mathrm{ml}$ solutions. The mixture ( $F$, also referred to as SAM) contained individual attractants in the same ratio as in the banana steamvolatiles.

Field bioassay: Traps containing hexanol alone, hexanol + aggregation pheromone or SAM alone did not attract weevils into traps. Traps baited with SAM + aggregation pheromone caught weevils with a variable weekly average, the maximum being $0.66 \pm 0.21$ weevils/trap. The control with the known attractant system, aggregation pheromone +banana stem tissue continued attracting weevils for 6 weeks with the highest weekly average catch of $29.16 \pm 7.02$ weevils/trap. (Table 2). The average weekly trap catches for the above two traps over 6 weeks ( $0.25 \mathrm{SD} \pm 0.24$ 
and 11.58 $\mathrm{SD} \pm 10.27$ respectively) were significantly different $(\mathrm{P}<0.05$, one way ANOVA \& Scheffer's test). In all traps approximately equal number of male and female weevils were caught (male: female=43:57).

\section{DISCUSSION}

Host volatile synergism with aggregation pheromones has been established for Curculionids in recent years. ${ }^{13,14}$. The host tissue + aggregation pheromone combination has always been a better lure for a particular pest species compared to that of aggregation pheromones + synthetic host volatiles. However, difficulties in the maintenance of host tissue in pheromone baited traps for long periods has made the above practice less popular. One good example is the aggregation pheromone baited trap of the date and coconut weevil, Rhynchophorus ferrugineus. Host volatiles of toddy, pieces of apple, coconut petioles, sugar cane etc. have been used successfully in the above pheromone trap, but with the need of weekly replacement. In extensive weevil control programs in the Middle Eastern date palm fields where several thousands of traps are deployed, the above traps have not shown much promise (unpublished observations of N.E. Gunawardena). In these instances alternatives have been the synthetic attractants having synergism with aggregation pheromone. Recent work on synthetic synergists for Curculionid aggregation pheromones has led to a large number of attractants. For example kiromonal synergism of ethyl alcohol for $R$. ferrugineus, ${ }^{12}$ ethylbutyrate for West Indian sugar cane weevil (WISW), ethylacetate for Rhynchophorus cruentatus and $R$. palmarum, ethylpropionate for $R$. phoenicis have been reported. ${ }^{15}$ Usually these compounds have been components of the respective natural host volatiles but their synergism has not been proximate to those of the respective host plant activity. In some cases, the host volatile synergism has been enhanced by the addition of synthetic attractants.

Our previous study showed that the synthetic aggregation pheromone baited trap was effective for $O$. longicollis only if banana stem tissue was present. ${ }^{8, "}$ Replacement of the banana stem tissue with a synthetic chemical or a mixture of chemicals was thought to open wider field applications for the above trap. In our preliminary laboratory behavioural bioassay, banana stem tissue alone was found to be attractive to the weevil, albeit at a short range $(70 \%$ weevils attracted to baited arm). In an EAG assay the banana steam distillate created similar response profiles for males and females but with a stronger response from the latter. This probably is indicative of the host volatile's plausible additional function as an oviposition stimulant for females.

Our identification of $\mathrm{n}$-pentanol, $\mathrm{n}$-hexanol, $\mathrm{n}$-hexanal and cis-3-hexenol as host attractants for $O$. longicollis is in conformity with the previous findings for Curculionids. Further, the Coleopteran's attraction to short chain aldehydes, acetates and alcohols has been well documented. ${ }^{15,16}$ EAG results of the present 
study indicated only hexanol as the potent synthetic attractant for the banana weevil (EAG $0.39 \mathrm{mV}$ ). However our field work proved that hexanol is neither a long-range attractant nor a synergist to the aggregation pheromone. In contrast, the synthetic attractant mixture (SAM) proved to be a synergist for the aggregation pheromone although poorly. Under the same field conditions it was also shown that the host tissue is a much better synergist for the aggregation pheromone. This suggests two possibilities: the presence of additional, as yet unknown banana stem kairomones or the production of different chemicals in the rotting banana stem tissue. In either case further work is necessary.

In conclusion, firstly, if there are undetected host kiromones present in the host tissue, it could be overcome by using a different method to collect banana stem volatiles. The presently used steam distillation method is often not the best way to collect volatiles for GC-EAD analysis although it was the easiest method available to us. Porapalk or headspace volatile collections are superior to steam distillation although the requirement of substantial amounts of volatiles by the former is a challenge. Secondly, rotting banana stem could be examined for new attractants.

\section{Acknowledgement}

We thank USAID for the research grant, Identification Service, CABI, International Institute of Entomology, London for identification of pest species and Dr. I.V.S.Fernando and Prof. U S Amerasinghe of the Department of Zoology University of Kelaniya, for their valuable assistance.

\section{References}

1 Chandraratna M.F. \& Nanayakkara K.D.S.S. (1951). Cultivated varieties of Banana in Ceylon. In Tropical Agriculture, Ceylon pp 70-91.

2 Samaratunga H. (1998). The present status of Banana Production in Sri Lanka, HORDI, Peradeniya.

3 Hill D.S. (1975). Agricultural Insect Pests of the Tropics and their Control. Cambridge University Press, 399-400 pp.

4 Beauhaire J., Ducrot P.H., Malosse C., Rochat D. Ndiege I. O. \& Otieno D.O. (1995). Identification and synthesis of Sordidin, a male pheromone emitted by Cosmopolite sordidus. Tetrahedron. Letters 36:1043-1046.

5. Abraham C.C. \& Thomas J. (1995). Mud slurry as base and carrier of insecticides for swabbing banana pseudostem against the weevil, Odoiporus longicollis. Journal of Insect Environmental 1 (2): 14. 
6 Regunath P., Visalakshi A., Mathew T.B., Mohandas N., Beevi S.N. \& Remamoni K.S. (1992). Insecticidal management of the pseudostem borer Odoiporus longicollis. Oliv. (Coleoptera: Curculionidae) Entomon 17(1-2): 113-115.

7 Smith D. (1995). Banana weevil borer control in South Eastern Queensland. Australian Journal of Experimental Agriculture 35(8): 1165-1172.

8 Gunawardena N.E., Dissanayake S., Herath K.B. \& Attygalle A.B. (1999). Isolation, Identification and synthesis of the aggregation pheromone of the banana stem borer, Odoiporus longicollis. Chemistry in Sri Lanka 16 (1):38.

9 Gunawardena N.E., Dissanayake S., Herath K.B. \& Attygalle A.B. (1997). 2- Methyl-4-heptanol and banana stem tissue baited trap to reduce the adult population of the banana stem borer, Odoiporus longicollis. Patent-Sri Lanka No 11337.

10 (Gumawardena N.E., Attygalle A.B. \& Herath H.M.W.K.B. (1989). The sex pheromone of the brinjal pest, Leucinoides orbonalis Guenee (Lepidoptera): problems and perspectives. Journal of the National Science Council of Sri Lanka 17 (2): 161-171.

11 Schneider D. (1957). Electrophysiologische untersuchugen von chemo und mechanorezeptoren der antenne des seidenspinnere Bombyx mori. L. Zeitschrift fur vergleichender Physiologie 40:8-41.

12 Gunawardena N.E. \& Herath K.B. (1994). Activity enhancement of ferrugineol by short chain alcohols:an attractant baited trap for the coconut pest, Rhynchophorus ferrugineus L. (Coleoptera: Curculionidae). Journal of the National Science Council of Sri Lanka 23(2):18-86.

13 Hallet R.H., Gries G., Gries R., Borden J.H., Czyzewska E., Oehlschlger A.C., Pierce H.D., Jr., Angerilli N.D.P \& Rauf A. (1993). Aggregation pheromones of two Asian palm weevils, Rhynchophorus ferrugineus and $R$. vulneratus. Naturwissenschaften. 80:328-331.

14 Giblin-Davis R.M., Weissling T.J. Oehschlager A.C. \& Gonzalez L.M. (1994). Field responses of Rhynchophorus cruentatus to its aggregation pheromones and fermenting plant volatiles. Florida Entomologist 77:164-177.

15 Giblin-Davis R.M., Oehlschlager A.C., Perez A., Gries G., Gries R., Weissling T.J., Chinchilla C.M., Pena J.E., Hallet R.H., Pierce H.D.Jr \& Gonzalez L.M..(1996). Chemical and behavioural ecology of palm weevils(Curculionidae: Rhynchophorinae). Florida Entomologist. 79(2):153-163. 
16 Gunawardena N.E. \& Kern F. (1994). Responses of the coconut pest, Rhynchophorus ferrugineus F.(Coleoptera: Curculionidae) to alcohols: electroantennogram assay. Journal of the National Science Council of Sri Lanka 22(1):25-33. 